\title{
THE EFFECTIVENESS OF THE BOARDING TEACHER PROFESSIONAL DEVELOPMENT PROGRAM: AN APPROACH OF PROCESS EVALUATION
}

\author{
Friyatmi \\ Doctoral Student at PPs UNY \& Lecturer at UNP \\ fri.yatmi@gmail.com
}

\begin{abstract}
This study aimed to evaluate the effectiveness of the implementation of the boarding Teacher Professional Development Program (PPG SM-3T) in State University of Padang (SUP). This research was an evaluation study using a part of the CIPP model, namely the process evaluation. The research questions for this study were 1) how is the effectiveness of the implementation of PPG SM-3T boarding program? 2) what are the weaknesses in implementing the PPG SM-3T boarding program in SUP? Data in this study were collecting using questionnaires and interview techniques. Informants of this study were the participants of the PPG SM-3T PSU and managers program. The data were analyzed using descriptive statistic techniques. The results of this study revealed that all over management of program implementation was considered less effective by the participants. The weaknesses of the program implementation are as follows. 1) The boarding education programs was less-organized, causing some programs were not function properly and often the schedule were not followed strictly; (2) Lack of coordination between the management and weakness supervision/controlling manager on the boarding activities resulted in less well executed program. (3) Meals service agent were less professional, resulting in the low quality and less variation food being served to the participants.
\end{abstract}

Keywords: Teacher professsion, PPG, boarding school for teachers

\section{INTRODUCTION}

Teacher quality plays an important role in educational process. Several efforts have been made by the Indonesian government to improve the teachers quality. Reference [1] reveals that the effort might be giving training, rotating, transferring, performance management and teachers career development programs. Althought the goverment has made various effort, some research on teachers performance indicate that teachers knowledge, skills and performance are below the teacher competency standards in many areas of Indonesia [2] [3]. Moreover, some research showed that the teacher's certification program has not positive impact on improving teachers performance [4,5].

To reduce the problem, the new policy has established by the goverment by issuing the government regulations about teacher professional development program. This program call Pendidikan Profesi Guru (PPG) which is a pre-service teacher education program for teachers candidat. After participating in the PPG programs, it is expected that the teacher candidates develop various professional teaching competencies. In addition, teachers are also develop soft skills such as environmental awareness, mental discipline, cooperative, and honest attitudes. International experience has shown that the implementation of teacher professional development program as a postgraduate program will provide the professional teacher [4].

The PPG programs are held by Lembaga Pendidikan Tenaga Keguruan (LPTK) which are teacher training institute in several universities appointed by Indonesian government. There are several type of PPG programs that have been implemented by the government, such as Integrated PPG, Collaborative PPG, and PPG SM-3T. Among those PPG programs, the PPG SM-3T is attended by many teachers candidates. SM-3T is named for a program of Sarjana Mendidik di daerah Terluar, Terdepan dan Tertinggal. It is a year teaching program for graduates in the Frontier, Outermost, and Disadvantaged Regions of Indonesia. To be involve in PPG SM$3 \mathrm{~T}$, a teacher candidate is required to participate in SM-3T program for one year. 
The puspose of PPG SM-3T program is to produce professional teacher candidates who have four competencies, i.e pedagogy, professional, personal, and social competence. The first two competencies are trained in workshops activities on campus, while the last two competencies fostered through boarding program.

As a boarding program, all participants of the PPG SM-3T program are stay and interact each other in a dormitory house for one year. The main goal of this program is to develop the personal and social competence of the participants. To achieve these objectives, facilities, instructors, curriculum, and learning materials are prepared thoroughly. The participants are requested to actively involved in various activities designed and facilitated in the boarding house. Various boarding programs have been designed to enhance the personal and social competence of the teacher candidats, including religious activities, tracing the individual talent, attitudes, aptitude and interest of participant, sports, arts performance, social and cultural activities, and mental development. The PPG SM-3T boarding program is more eager to highlight the mastery of personal and social competence so that might be expected to produce a professional and qualified teachers. The PPG SM-3T boarding program has been implemented since 2013 and has succeeding in its outcome in professional teacher candidates who have been certified as profesional educators.

This program is funded by the national government, with an expectation that in the long time, the program would produce prospective teachers with noble character and professional competence. A boarding training and education system requires a substantial amount of funding from the government.

Boarding shool programs is not a new concept in the context of Indonesian education system. Boarding education has been widely implemented in primary and secondary schools, ranging from Islamic traditional boarding school well known as pondok pesantren, to modern boarding secondary senior school as well as other religious based schools system. This boarding school concept was adopted to foster the professional teacher candidates in the form of PPG SM-3T boarding program. A concern is being made, as the participants of this boarding education programs are adult teachers candidate, who are considered to be able to develop their own character. In fact, those participant of SM-3T program already had their experience of teaching in challenging areas and far away from their families, but they were able to survive. They were able to socialize with the community and think creatively in facing various limitation in the frontier area.

An evaluation is needed to analyzed the effectiveness of the boarding PPG SM-3T program. It is necessarry to find the weakness of various aspects of the program, then it can be easily to perform improvement treatment. This research aimed to evaluate the process of PPG SM-3T boarding program at State University of Padang (SUP). The problem raised are (1) how is the effectiveness of the implementation of PPG SM-3T boarding program organized by SUP? (2) what are the weaknesses in implementing the PPG SM-3T boarding program organized by SUP?

\section{RESEARCH METHODS}

This research utilized part of the CIPP evaluation model (Context, Input, Process and Product), where the emphasize is in the process evaluation of the PPG SM-3T boarding program. Sample for this research was selected by proportional random sampling technique from paticipants and the managers of boarding program who participate in the 3rd batch of PPG SM3T year 2015 at SUP. Data was collected through questionnaire and interview. The questionnaire was administered to evaluate the process of PPG SM-3T boarding program. Interview was conducted to the participants and program managers to analyze the constrains or obstacles in implementing the process of boarding program at Padang State University, West of Sumatra. The effectiveness of the implementation of PPG SM-3T boarding program was assessed through following indicators: 1) the managing of program implementation, 2) the strategy of program implementation, 3) developing of personal competence program, and 4) developing of social competence program. The data was analyzed using statistic descriptive analysis. The evaluation findings of this research was compared to the prescribed evaluation criteria. The criteria are follow, 1) score $X \geq 3$ shows a high criteria (effective), 2) score $2 \leq X<3$ means moderate categori (less effective), and 3 ) score $X<2$ shows poor criteria (not effective). 


\section{RESEARCH FINDING AND DISCUSSION}

\section{A. The Effectiveness of The Process of PPG SM-3T Boarding Program}

The finding of this study indicate that the process of PPG SM-3T boarding program for the year 2015 at SUP were rated in the moderate category as shown in Table 1 below.

Table 1. Results of Evaluation Process of PPG SM-3T Boarding Program

\begin{tabular}{|c|l|c|c|}
\hline No & Component & Average & Category \\
\hline 1 & Managing of program implementation & 2.31 & Moderate \\
\hline 2 & Strategy of program implementation & 2.37 & Moderate \\
\hline 3 & Developing of personal competence program & 2.49 & Moderate \\
\hline 4 & Developing of social competence program & 2.86 & Moderate \\
\hline
\end{tabular}

The PPG SM-3T boarding program is intended to prepare teachers candidate to become professional teacher and having personal dan sosial competence. In this study, although the implementation of both programs are in the moderate category, but the score social competence development higher than other indicators. The interaction among the participants was in good category, with average score of 3.14 , while the interaction between the participants with the boarding manager is at moderate category as like as the implementation of the development program for personal skills i.e the conveying of the discipline, attitude, creativity, responsibilty, spriritual \& character development programs.

Character building is an important key in the implementation of PPG SM-3T boarding programs. Therefore, practice and habituation are two main principles introduced in that programs. The participants were trained to be obedient to the guiding norms and habituating those norms in their daily life. These principles generally are applied in all group activities in their boarding life. These practice and habituation are expected to become culture in the daily life. Reference [6] opined that one strategy leading into character development is through habituation. Habituation may lead behaviour become permanent character. Based on the observation to the participants of the PPG SM-3T, these principle had been implemented and habituated among them. For example, close and intense interaction among the participants could be seen in all group activities, e.g praying, eating, learning together, despite they come from diverse region, culture, and custom from all region in Indonesia. The concept of boarding school has a significant influence on the social competency development of the students because the boarding life can be used as a tool to improve the spirit of brotherhood and cultural identity 77 . Participants of PPG SM-3T were coming from a very diverse social and cultural backgrounds, the boarding life develop close relationship among the participants and also they learn about others culture. These skill are essential for the teachers to prepare them entering and adapting to their working place. It is very important for the PPG participants to support their duties and responsibility as teachers, after they graduated from the program, and return to their respective rural areas in Indonesia.

Implementation of various boarding program can improve the spirituality, mental health, talents and interest of participants. Based on the researcher observation, the Moslem participants held religious studies and discussion to increase their spirituality regularly. The similar program also given to other participants who belongs to other religious denomination. In addition, art and cultural performance also given every Saturday to accommodate and develop participants respective talents and interest.

The lack of the effectiveness of the program implementation caused by the the strategy of the program has not been maximized. The method of program implementation and its compliance with the program schedule was also rated moderate by the participants with average scores respectively are 2.42 and 2.40 . The lowest score of the implementation of boarding was at the performance of instructors/speakers with the average of 2.36 .

Although the efectiveness of the implementation of boarding program was rated moderate, the managing of program implementation were rated lower than other indicators. That related to consumption management, environmental hygiene \& security in dorm, and the supervision of the 
manager. based on that four aspect, consumption management is at low category while the others were at moderate category.

The objective of boarding program is to buliding character among the teachers candidate with high achievement, mastering life skills, and enjoying healthy life. To achieve that objective, participants are provided with dormitory equipped, facilities, and basic needs, including healthy food. Participants are mandatory to get three times daily meals. Research finding indicated that the quality of meals being served daily at the dormitory was at low category with score 1.9. Based on the interview with boarding management, the catering agency selected were less professional. Less food variations, less food quality and less tasty meals served daily lead into dissatisfaction of the participant. Research [8] revealed that boarding education has benefits for students to have a positive life patterns, which is supported by a nutritious food. The committee should improve the consumption management to ensure the nutrition and the healthy of participants.

Participant also considered the lack of supervision by the program administrator and boarding house management as well as the lack of evaluations done by the administrator. Interview with the boarding management indicated that the evaluation on the boarding life was not done regularly, and it involved only limited participants who were selected as boarding committee members. It intended to increase the effectiveness of evaluation process. The existence of evaluation is very important in an program because it can beneficial to the development and quality program improvement 9 .

\section{B. The Weaknesses in Implementing The PPG SM-3T Boarding Program}

In addition to administered questionnaire, a number of closed questions were given to participants and boarding managers of PPG SM-3T to identify the weaknesses of the program. Based on the answer to those questions by the participants and managers, in general the shortcomings of the PPG SM-3T boarding program were focused on the following points: 1) The boarding programs was less-effective, causing some programs were not function properly and often the schedule were not followed strictly; 2) Lack of coordination between the management and weakness supervision/controlling manager on the boarding activities resulted in less well executed program. 3) Meals service agent were less professional.

The finding from evaluation process of PPG SM-3T boarding program organized by Padang State University indicated that it was not up to the maximum success, due to several factors. These factors were not interrelated each other, neither they would affect the other components of the boarding program. Based on the research finding, these factors were lacking of coordination among the members of the boarding program organizers, lack of supervision, and unsatisfactory food services.

The main foundation for a successful boarding program is the availability of team works who are able to design and supervise the whole program according to the desired goal. In this respect, program planning play the most important role. Communication and coordination amongst the program organizer need to be maintained strictly, to ensure the whole component of the program functioning properly.

\section{CONCLUSION}

The goal of PPG SM-3T is to increase the teachers quality by developing four teacher competencies which are (1) pedagogical competency; (2) professional competency; (3) social competency; and (4) personality competency. The emphasize of the boarding program is the development of social competency and personality competency by close interactions and association among the participants while they stay in the dormitory for one year.

Evaluation on the process of PPG SM-3T of SUP boarding program indicated that all over management of program implementation was considered less effective by the participants. The weakness of the program include the following areas: (1) The boarding education programs was less-organized, causing some programs were not function properly and often the schedule were not followed strictly; (2) Lack of coordination between the management and weakness supervision/controlling manager on the boarding activities resulted in less well executed program. (4) Meals service agent were less professional, resulting in the low quality and less variated food being served to the participants.

Based on the research finding, recommendation are given to improve the quality of the PPG SM-3T boarding program in the future. The program organizer should improve their managerial 
system by implementing the planning, organizing, actuating, and controlling functions. More specifics recommendation are given for the following areas: (1) There is a need to improve the role of boarding management committee members by establishing job description and responsibility of each program components, based on the guidelines given by the Directorate of Higher Education, Minister of Education and Culture of Indonesia; (2) To recruit more professional and more than one catering agents to enable more varieties of food being served to the participants; (3) To implement a continuing supervision system to control the discipline of participants while attending the PPG SM-3T boarding program.

\section{REFERENCE}

[1] Iswari, M., Membina Perkembangan Emosi Remaja Meningkatkan Profesional Guru. Pedagogi, Jurnal IImiah IImu Pendidikan, 2009. IX(1).

[2] Tanang, H. and B. Abu, Teacher Professionalism and Professional Development Practices in South Sulawesi, Indonesia. Journal of Curriculum and Teaching, 2014. 3(2): p. 25-42.

[3] Bank, T.W., Transforming Indonesia's Teaching Force. 2010, The Word Bank

[4] Chang, M.C., et al., Teacher Reform in Indonesia: The Role of Politics and Evidence in Policy Making. 2014, The Word Bank: Washington, DC

[5] Hurmaini, M., Dampak Pelaksanaan Sertifikasi Guru terhadap Peningkatan Kinerja Guru dalam Proses Pembelajaran: Studi pada Madrasah Tsanawiyah Negeri Kota Jambi. Media Akademika 2011. 26(4).

[6] Miftah, M., Pengembangan Karakter Anak Melalui Pembelajaran IImu Sosial. Jurnal Pendidikan Karakter, 2013. III(2).

[7] Graham, A.G., The Power of Boarding Schools, A Historiographical Review. American Educational History Journal, 2012. 39(2).

[8] Curto, V.E. and R.G. Fryer, The Potential of Urban Boarding Schools for the Poor: Evidence from SEED. Journal of Labor Economics, 2014. 32(1): p. 28.

[9] Stavropoulou, A. and T. Stroubouki, Evaluation of Educational Programmes - The Contribution of History to Modern Evaluation Thinking. Health Science Journal, 2014. 8(2). 